\title{
Nd: YAG LASER ANTERIOR CAPSULOTOMY IN CAPSULAR PHIMOSIS IN THE EYE WITH PEX AND ZONULAR LESION
}

\author{
Aleksandar Veselinović, Marija Cvetanović, Dragan Veselinović
}

\begin{abstract}
Secondary cataract formation is significantly present after cataract surgery and develops at different time intervals after the intervention. Blepharophimosis or anterior capsule contraction may result in numerous problems in the operated eye. In patients with cataract associated with pseudoexfoliation syndrome the risk of anterior capsule contraction is greater, especially if small capsulorhexis had previously been performed.

The paper presents blepharophimosis of the anterior capsule with phacodonesis and secondary cataract eight months after phacoemulsification with intraocular lens implantation. Due to anterior capsule opacification and formation of capsular phimosis, visual acuity decreased and monocular diplopia developed in the operated eye. After sectoral YAG laser capsulotomy of adjustable intensity was performed, visual acuity improved and the patient's subjective complaints disappeared.

YAG laser capsulotomy is a significant method in managing secondary cataract. Management of secondary cataract due to anterior lens capsule opacification and the presence of anterior capsule phimosis associated with expressed pseuoexfoliations and zonular lesion poses a particular challenge to ophthalmologists and requires a certain amount of experience in the management of these conditions.
\end{abstract}

Acta Medica Medianae 2020;59(1):144-148.

Key words: YAG laser capsulotomy, capsular phimosis, pseudoexfoliation

Ophthalmology Clinic, Clinical Center Niš, Niš, Serbia

Contact: Aleksandar Veselinović

48 Dr. Zoran Djindjić Blvd., 18000 Niš, Serbia

E-mail: veselinovic.aleksandar@gmail.com

\section{Introduction}

Capsular phimosis or anterior capsule contraction syndrome has been described as one of the potential complications in patients with cataract. Capsular phimosis occurs as a postoperative complication resulting from a small diameter capsulorhexis and postoperative inflammatory reactions in the eye $(1,2,3,4)$. After cataract surgery residual lens epithelial cells may proliferate over the posterior lens capsule and on the intraocular lens surface as well, causing myofibroblast transdifferentiation (4, 5). A small capsulorhexis diameter most commonly presents a risk for capsular phimosis either as a consequence of inexperience of the surgeon or due to a small pupil size in cataract patients. Most commonly registered associated condition is pseudo- exfoliation syndrome, but it has also been described in patients with retinitis pigmentosa, diabetes, uveitis and Behcet's syndrome, high myopia, uveitis, pars planitis, and myotonic dystrophy $(5,6,7,8,9)$. A small anterior capsule opening makes surgery more difficult and may cause numerous intraoperative complications. Capsular contraction syndrome may also occur after combined cataract and glaucoma surgery and due to intraoperative complications that may result in prolonged postoperative inflammation. According to some authors' experience, intraocular lens material, especially haptic lenses, may be contributing factors for capsular phimosis $(10,11,12,13)$.

Postoperatively, subsequent constriction of the anterior capsular opening may occur, capsular phimosis, as a consequence of proliferative and inflammatory processes. Severe anterior lens constriction, especially in patients with pseudoexfoliation syndrome, may result in subluxation of artificial lenses due to zonular lesions. As a consequence of severe anterior lens constriction, tractional ciliary body detachment may also occur accompanied with choroidal effusion $(14,15)$.

\section{Case report}

Patient Z.M. aged 72, presented to her doctor with the complaints of monocular diplopia and de- 
creased vision in the last three months in the left pseudophakic eye. She had had her left eye operated for cataract eight months before she came to see her doctor, with performed phacoemulsification of mature cataract in the eye with pseudoexfoliation glaucoma. A single-piece, hydrophilic acrylic lens with two haptics was implanted during the surgery. The postoperative course was normal. The aforementioned problem with a small size pupil was associated with smaller capsulorhexis during the surgery, but it did not affect the course of the operation. Postoperative visual acuity in the left, operated eye after seven days was 1.0. Three months after the operation the patient reported decreased visual acuity in the left eye with occasional signs of diplopia. The symptoms intensified in the last few weeks. On examination, visual acuity was 0.5 with the presence of phimosis and fibrosis on the inferior portion of the anterior lens capsule. The deposition of pseudoexfoliation material was noted on the anterior capsule and on the zonulae. Zonular defect was evident at the 5-6 o'clock position. Incipient cataract with pseudoexfoliation changes of the pupillary rim was present in the other eye. Intraocular pressure in both eyes was 18 $\mathrm{mmHg}$ with topical antiglaucomatous therapy sol. Cosopt $2 \times 1$.

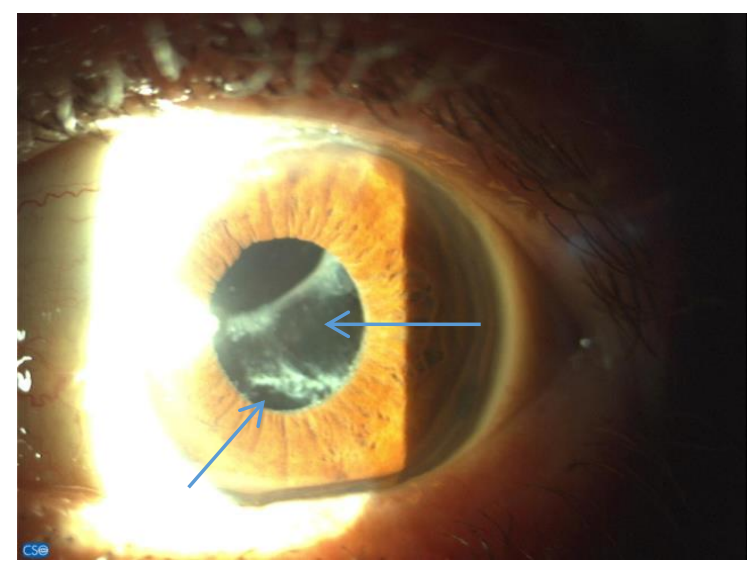

Figure 1. Pseudophakic eye with PEX with secondary cataract and capsular phimosis

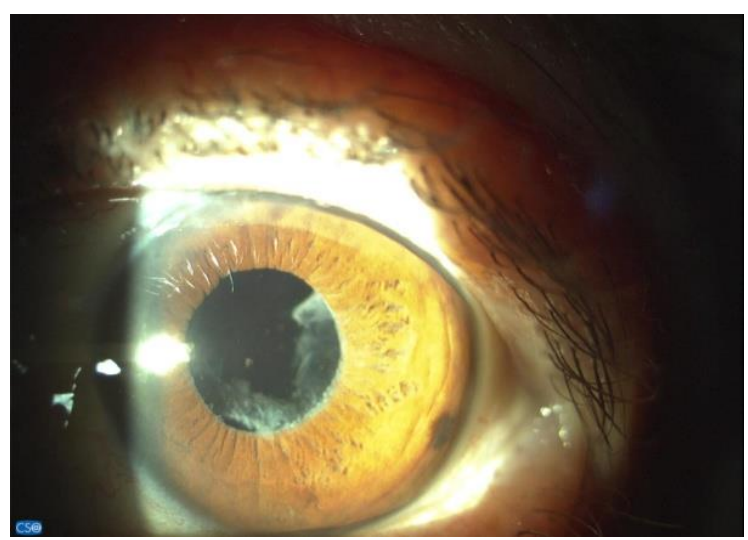

Figure 3. Triangle Yag capsulotomy

YAG laser capsulotomy was performed using 7 shots, power level of $5 \mathrm{~mJ}$, with extreme caution regarding zonular weakness in the sector of the performance. The first shot by YAG laser was performed at the very edge of capsulorrhexis where the greatest thickening of the anterior capsule was pre-

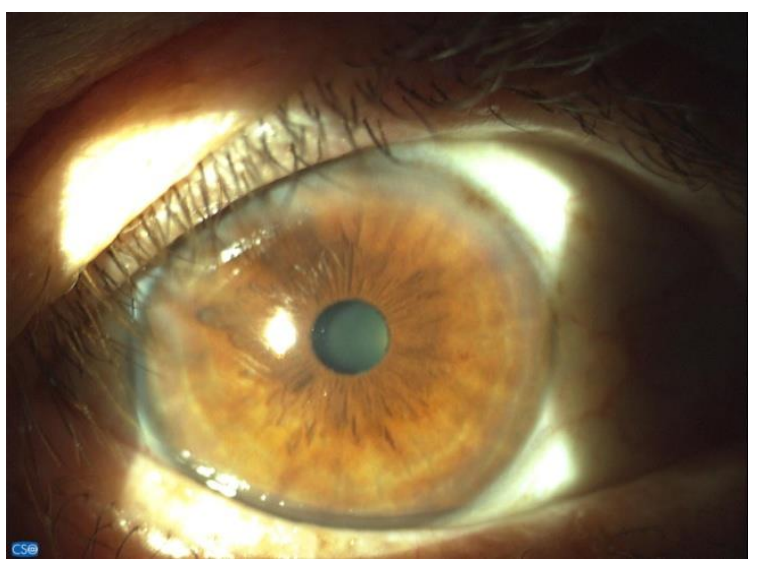

Figure 2. The other, 'healthy eye'

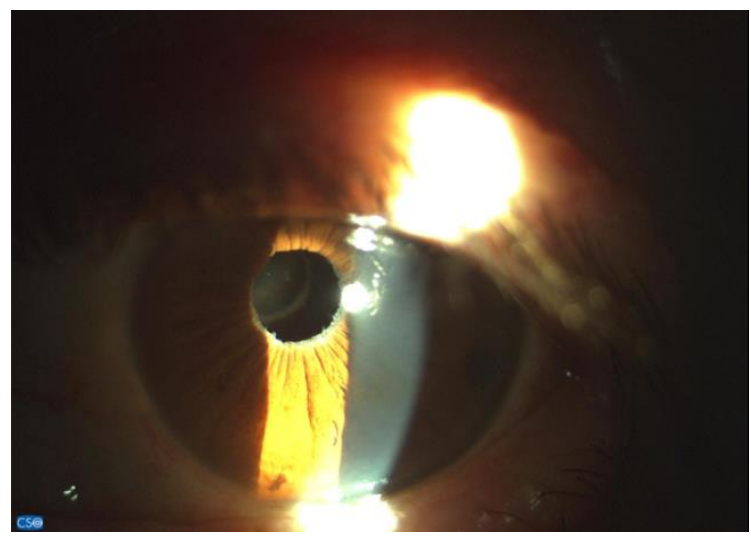

Figure 4. Patient's eye 7 days after the intervention

sent, causing higher power level of $5 \mathrm{~mJ}$ to be used. A triangle opening was created later and the visual acuity was improved, VOS: 0.8. Prescribed therapy for the patient included sol. Neodexacin $3 \times 1$ and tbl. Huma-Zolamide $1 \times 1$ for their anti-inflam- 
matory properties and because of possible transient increase of intraocular pressure.

Follow-up examination revealed that visual acuity in the left eye was 1.0, IOP: $18 \mathrm{mmHg}$ with regular antiglaucomatous treatment. The patient had no more complaints of diplopia and was satisfied with the effects of the intervention.

\section{Discussion}

Anterior capsular contraction syndrome has multiple causes and its occurrence can greatly diminish primary effect of cataract surgery. The most common causes of capsular phimosis include a small diameter capsulorhexis in patients with chronic inflammatory processes, uveitis, diabetes and pseudoexfoliation syndrome $(2,3,4)$. Good postoperative acuity in these patients may greatly be decreased and result in patient's condition similar to preoperative one. If a tendency for capsular phimosis is noted in early postoperative period, relaxing radial incisions along the rim may be performed using the YAG laser to prevent further constriction (16). Due to strong contractions and intraocular lens decentration, monocular diplopia, glare and binocular vision problems are very common.

Application of the YAG laser is of extreme importance in secondary cataract treatment and in patients with postoperative anterior capsular contraction. A special problem in performing the YAG laser anterior capsulotomy in blepharophimosis is a condition accompanied with zonular lesion, as well as phacodonesis and intraocular lens decentration. In patients with blepharophimosis it is necessary to perform anterior capsulotomy requiring adjustment of the laser shock waves intensity in order not to damage anterior surface of the artificial lens. In some cases, it is necessary to use YAG laser with higher intensity due to anterior capsular thickening and fibrosis, which makes correct dosage and the surgeon's experience very important. Additional YAG laser treatment, due to exerted stress on the zonulae, may in some cases produce more zonular lesions and lens decentration, thus increasing monocular diplopia intensity and the patient's subjective visual disturbances. In severe contraction syndrome dislocation of artificial lens towards the vitreous body is often present, resulting in refractive changes and hypermetropia. The YAG laser anterior capsulotomy results in capsular bag relaxation and a possible refractive change regarding the reduction of hypermetropia (17). There were no refractive anomaly changes in our patient.

\section{Conclusion}

Before anterior laser capsulotomy is performed, the evaluation of anterior capsular blurriness and fibrosis degree should be evaluated to determine the intensity of the laser beam. Anterior capsular extension must not be performed in the direction of zonular defects and the first wave shot should be directed to capsulorhexis edge. A triangular anterior capsule opening in the eye with dilated pupil should be big enough to avoid glare that may be caused by peripheral portion of anterior capsular remnants after normal pupil size is achieved. 


\section{References}

1. Joo CK, Shin JA, Kim JH. Capsular opening contraction after continuous curvilinear capsulorhexis and intraocular lens implantation. J Cataract Refract Surg 1996; 22:585-90. [CrossRef] [PubMed]

2. Davison JA. Capsule contraction syndrome. J Cataract Refract Surg 1993; 19:582-9. [CrossRef] [PubMed]

3. Kurosaka D, Ando I, Kato K, Oshima T, Kurosaka H, Yoshino $\mathrm{M}$, et al. Fibrous membrane formation at the capsular margin in capsule contraction syndrome. ] Cataract Refract Surg 1999; 25:930-5. [CrossRef] [PubMed]

4. Gills JP. Anterior capsule contraction. J Cataract Refract Surg 2003; 29:1652. [CrossRef] [PubMed]

5. Hayashi H, Hayashi K, Nakao F, Hayashi F. Anterior capsule contraction and intraocular lens dislocation in eyes with pseudoexfoliation syndrome. $\mathrm{Br}$ J Ophthalmol 1998; 82:1429-32. [CrossRef] [PubMed]

6. Hayashi H, Hayashi K, Nakao F, Hayashi F. Area reduction in the anterior capsule opening in eyes of diabetes mellitus patients. J Cataract Refract Surg 1998; 24:1105-10. [CrossRef] [PubMed]

7. Jin-Poi T, Shatriah I, Khairy-Shamel ST, Zunaina E. Rapid anterior capsular contraction after phacoemulsification surgery in a patient with retinitis pigmentosa. Clin Ophthalmol 2013; 7:839-42. [CrossRef] [PubMed]

8. Najjar DM, Igbre AO, Tsai FF. Late capsular bag contraction and intraocular lens subluxation in retinitis pigmentosa: a case report. J Med Case Rep 2011; 5:65. [CrossRef] [PubMed]

9. Alintas AGK, Dal D. Capsule contraction syndrome in Behcet's disease. Int J Ophthalmol 2010; 3:358-60. [CrossRef] [PubMed]
10. Cochener B, Jacq PL, Colin J. Capsule contraction after continuous curvilinear capsulorhexis: poly (methyl methacrylate) versus silicone intraocular lenses. J Cataract Refract Surg 1999; 25:1362-9. [CrossRef] [PubMed]

11. Gonvers M, Sickenberg M, Van Melle G. Change in capsulorhexis size after implantation of three types of intraocular lenses. J Cataract Refract Surg 1997; 23:231-8. [CrossRef] [PubMed]

12. Toldos JJM, Roig AA, Benabent EC. Total anterior capsule closure after silicone intraocular lens implantation. J Cataract Refract Surg 1996; 22:269-71. [CrossRef] [PubMed]

13. Apple DJ. Influence of intraocular lens material and design on postoperative intracapsular cellular reactivity. Trans Am Ophthalmol Soc 2000; 98: 257-83. [PubMed]

14. Srinivasan S, van der Hoek J, Green F, Atta HR. Tractional ciliary body detachment, choroidal effusion, and hypotony caused by severe anterior lens capsule contraction following cataract surgery. $\mathrm{Br}$ J Ophthalmol 2001; 85:1261-2. [CrossRef] [PubMed]

15. Salzmann J, Khaw PT, Laidlaw A. Choroidal effusions and hypotony caused by severe anterior lens capsule contraction after cataract surgery. Am J Ophthalmol 2000; 129:253-4. [CrossRef] [PubMed]

16. Hayashi K, Yoshida M, Hirata A, Hayashi H. Anterior capsule relaxing incisions with neodymium: YAG laser for patients at high-risk for anterior capsule contraction. J Cataract Refract Surg 2001; 37:97-103. [CrossRef] [PubMed]

17. Abd Elmagid M, Tag Eldin. Refractive change after YAG laser anterior capsulotomy in capsular phimosis syndrome. Journal of American Science 2014; 10(8). 


\title{
Nd: YAG LASER KAPSULOTOMIJA PREDNJE KAPSULE KOD KAPSULOFIMOZE U OKU SA PEX-OM I LEZIJOM ZONULA
}

\author{
Aleksandar Veselinović, Marija Cvetanović, Dragan Veselinović
}

Klinika za očne bolesti, Klinički centar Niš, Niš, Srbija

Kontakt: Aleksandar Veselinović

Bulevar dr Zoran Đinđić 48, 18000 Niš, Srbija

E-mail: veselinovic.aleksandar@gmail.com

Pojava sekundarne katarakte nakon operacije katarakte prisutna je u značajnom broju i nastaje u različitom vremenskom periodu od intervencije. Blefarofimoza ili konstrikcija prednje kapsule može prouzrokovati brojne probleme na operisanom oku. Kod bolesnika kod kojih je katarakta udružena sa pseudoeksfolijacionim sindromom postoji veći rizik za nastanak kon-strikcije prednje kapsule, posebno ukoliko je predhodno urađena mala kapsuloreksa.

$\mathrm{U}$ radu je dat prikaz pojave blefarofimoze prednje kapsule, sa fakodonezom i sekundarnom kataraktom, osam meseci nakon urađene fakoemulzifikacije sa ugradnjom intraokularnog sočiva. Usled zamućenja prednje kapsule sočiva i pojave kapsulofimoze, došlo je do smanjenja oštrine vida i pojave monokularnih diplopija na operisanom oku. Nakon izvođenja sektoraste YAG laser kapsulotomije dozirane snage, došlo je do poboljšanja oštrine vida i gubitka subjektivnih tegoba bolesnice.

Yag laser kapsulotomija prestavlja značajnu metodu u rešavanju pojave sekundarne katarakte. Rešavanje problema sekundarne katarakte usled prisustva zamućenja prednje kapsule sočiva i prisustva fimoze prednje kapsule, udružene sa izraženim pseudoeksfolijacijama i lezijom zonula, predstavlja poseban izazov za oftalmologa i zahteva iskustvo u rešavanju ovakvih stanja.

Acta Medica Medianae 2020;59(1):144-148.

Ključne reči: Yag laser kapsulotomija, kapsulofimoza, pseudoexfoliatio 